\title{
VALIDASI LUAS LAHAN TAMBAK DI KABUPATEN PINRANG, PROVINSI SULAWESI SELATAN DENGAN MENGGUNAKAN TEKNOLOGI PENGINDERAAN JAUH DAN SISTEM INFORMASI GEOGRAFIS
}

\author{
Mudian Paena*), Akhmad Mustafa*), Hasnawi*), dan Rachmansyah*)
}

\begin{abstract}
ABSTRAK
Keberhasilan budi daya tambak udang windu pada awal tahun 1990-an menyebabkan terjadinya pertambahan luas tambak yang cukup besar di Sulawesi Selatan termasuk di Kabupaten Pinrang. Untuk mendapatkan data perubahan luas dan luas tambak terkini di kabupaten tersebut maka dilakukan validasi luas tambak melalui pemanfaatan citra satelit. Citra satelit yang digunakan adalah Landsat-7 ETM+ akuisisi 2002 dan 2005 yang selanjutnya dilakukan klasifikasi. Sedangkan untuk data sebelumnya yaitu tahun 1991 digunakan peta rupabumi Indonesia yang didigitasi dan dilakukan analisis spasial dengan menggunakan SIG. Hasil analisis menunjukkan bahwa luas tambak di Kabupaten Pinrang pada tahun 1991 adalah 7.490,805 ha dan meningkat pada tahun 2002 dan 2005 menjadi berturut-turut 13.366,086 ha dan 14.569,180 ha. Penambahan luas tambak di Kabupaten Pinrang sebagian besar berasal dari konversi sawah dan sebagian lagi berasal dari konversi penggunaan lahan lainnya yang ada di kawasan pesisir.
\end{abstract}

ABSTRACT: Updating of brackish water pond area in Pinrang Regency, South Sulawesi Province by using remote sensing and geographical information systems technologies. By: Mudian Paena, Akhmad Mustafa, Hasnawi, and Rachmansyah

The successful of tiger prawn culture in the brackish water pond in the early of 1990 s to cause expansion of brackish water pond area in fairly large in South Sulawesi including Pinrang Regency. To find data of area changing and updating data of brackish water pond area in this regency, was conducted the validation brackish water pond area with satellite image. Satellite image which used was Landsat-7 ETM+ acquisition 2002 and 2005. Satellite image was classified, while the early data, in 1991, was used maps of rupabumi Indonesia that was digitized and conducted spatial analysis with GIS. The results of analysis show that brackish water pond area in Pinrang regency in 1991 was 7,490.805 ha and increased up to 13,366.086 ha and $14,569.180$ ha in 2002-2005, respectively. The addition of brackish water ponds area in Pinrang Regency was mainly came from conversion of paddy field and it remaining was from the other land uses type of coastal zone.

KEYWORDS: updating, brackish water ponds, remote sensing, GIS, Pinrang Regency 


\section{PENDAHULUAN}

Keberhasilan budi daya udang windu di tambak pada awal tahun 1990-an merupakan penyebab terjadinya peningkatan luas tambak di Kabupaten Pinrang Provinsi Sulawesi Selatan. Konversi sawah menjadi tambak banyak dilakukan dengan pertimbangan terjadinya peningkatan pendapatan sebagai pembudi daya tambak (Sanusi, 2001). Perubahan penggunaan lahan yang demikian ini menyebabkan adanya perubahan ekosistem, karakteristik lahan, dan tipologi pantai serta potensi kawasan pertambakan. Untuk mengantisipasi kerusakan dan menjaga kelestarian sumber daya lahan sekaligus peningkatan produktivitas, maka pemberdayaan sumber daya lahan tersebut harus dikelola dan direncanakan sebaik mungkin (Mustafa et al., 2004).

Pengembangan usaha budi daya perikanan pesisir berbasis tambak dapat dilakukan pada kawasan pesisir yang memiliki kondisi lingkungan yang sesuai untuk persyaratan lokasi tambak antara lain: adanya sumber air laut dan tawar, variasi pasang surut antara $150-250 \mathrm{~cm}$, topografi relatif landai, kualitas tanah tertentu yang ditentukan oleh teknologi yang akan diterapkan, curah hujan kurang dari $2.000 \mathrm{~mm} /$ tahun dan bebas dari banjir, gelombang besar, arus kuat serta bebas cemaran, kelengkapan dan kemudahan fasilitas, kemudahan pemasokan sarana produksi tambak dan pemasaran, sesuai tata guna lahan, dan kebijakan pemerintah (Ahmad et al., 1996). Pengembangan budi daya tambak yang tidak sesuai dengan daya dukung lahan berdampak pada rendahnya produktivitas dan tidak berlanjut, seperti kasus yang dijumpai di Kecamatan Pangkajene, Kabupaten Pangkep pada daerah tersebut tingkat produktivitas tambak terus mengalami penurunan sehingga banyak tambak yang tidak dapat dioperasikan secara optimal (Mustafa \& Hanafi, 1996). Kriteria kelayakan lahan dapat bervariasi dari satu tempat ke tempat lain, namun pada umumnya yang penting didasarkan pada faktor-faktor meteorologi, tanah, topografi, dan ketersediaan air, di mana kategori penting dari informasi lingkungan dibutuhkan untuk penilaian kelayakan lahan (Dennis et al., 2004; Salam et al., 2005). Kelayakan lahan merupakan suatu kunci sukses dalam kegiatan akuakultur yang mempengaruhi kesuksesan dan keberlanjutannya (Pérez et al., 2003).
Hal tersebut di atas memberikan gambaran bahwa berbagai alternatif telah dilakukan untuk meningkatkan produktivitas tambak. Namun demikian upaya tersebut terus mengalami fluktuasi, sebagai akibat dari kompleksnya permasalahan yang terjadi dalam budi daya tambak, terutama kualitas lingkungan biofisik dan kimia air serta tanah sebagai akibat dari perubahan kondisi lingkungan regional di luar atau di sekitar lokasi tambak seperti permukiman, industri, lahan pertanian, dan penggunaan lahan lainnya. Salah satu cara untuk meminimalkan dampak negatif dari permasalahan yang ada dalam budi daya tambak adalah dengan melakukan perencanaan penggunaan lahan sehingga mempermudah kontrol kualitas lingkungan. Untuk mengimplementasikan hal tersebut dibutuhkan sebuah basis data luas tambak yang tepat.

Luas tambak di Kabupaten Pinrang yang dilaporkan oleh berbagai sumber memiliki angka yang berbeda-beda, dan juga tidak dijelaskan metode perolehan datanya. Hal ini memberikan keraguan apabila digunakan sebagai referensi. Perhitungan luas tambak aktual dapat dilakukan dengan dua metode umum yaitu sensus dan teresterial. Metode sensus memiliki kelebihan terutama hemat dalam waktu dan biaya tetapi kelemahan yang mungkin terjadi adalah munculnya bias data yang sangat besar. Metode teresterial ini memiliki kelebihan yaitu data yang dihasilkan memiliki tingkat ketelitian yang tinggi, sedangkan kelemahannya memerlukan waktu survai yang lama dengan kebutuhan dana yang sangat besar. Metode ini hanya efektif digunakan pada lahan yang sempit. Perkembangan dan kemajuan teknologi telah memberikan dampak munculnya metode baru untuk menghitung luasan tambak, metode tersebut adalah pemanfaatan teknik penginderaan jauh dan Sistem Informasi Geografis (SIG).

Pemanfaatan teknik penginderaan jauh dan SIG dalam menentukan luas tambak dianggap lebih efektif karena memiliki tingkat ketelitian yang tinggi, hemat biaya, dan mengurangi pekerjaan teresterial. Selain itu, data yang dihasilkan dari teknik ini dapat disajikan secara spasial dalam bentuk peta sehingga dapat dilakukan evaluasi dan pemantauan pola distribusi tambak dan kemungkinan perubahannya. Dengan demikian data hasil kajian ini dapat 
dimanfaatkan untuk sebagai validasi data luas tambak di Kabupaten Pinrang.

Data yang akurat dan aktual mengenai luas tambak serta pola perkembangan spasialnya akan memberikan manfaat bagi semua stakeholder budi daya tambak. Hal ini penting terutama dalam perencanaan jumlah dan kualitas teknologi yang diterapkan serta sarana produksi lainnya, pemilihan manajemen, dan kemungkinan skala pengelolaan, ketepatan perencanaan anggaran dan rekayasa keuntungan, perencanaan penggunaan, dan alih fungsi lahan, serta rencana pembangunan makro.

Penelitian ini bertujuan untuk mengetahui luas tambak yang akurat dan terkini di kawasan pesisir Kabupaten Pinrang sebagai basis data untuk pengelolaan tambak yang berkelanjutan.

\section{BAHAN DAN METODE}

Diagram alir dalam penentuan luas Iahan budi daya tambak disajikan pada Gambar 1 . Sumber data yang digunakan dalam kajian ini adalah Citra Landsat-7 ETM+ tahun 2002 dan 2005. Citra Landsat dapat digunakan untuk mengetahui perubahan penggunaan dan penutupan lahan (Lo, 1996; Kushardono, 1999; Sitanggang, 1999). Untuk mencakup lokasi penelitian dibutuhkan 1 scene yaitu: Path/Row 114/63 masing-masing untuk setiap waktu yang berbeda. Dokumen lain berupa Peta rupabumi Indonesia Lembar Parepare, Lembar Pinrang, Lembar Lampa, dan Lembar Paria, masing-masing skala 1:50.000 edisi tahun 1991 dibutuhkan dalam pembuatan peta dasar digital.

Penajaman citra dengan cara modifikasi kontras data citra untuk memperoleh perbedaan yang lebih jelas antara setiap objek pada citra dengan bantuan Program Er Mapper 6.4. Untuk mengurangi pengaruh kecerahan/ kegelapan dari titik citra di dalam citra maka dilakukan penapisan citra. Reduksi kanal dilakukan dengan menggunakan Metode Pemilihan Kombinasi Kanal Spektral.

Reduksi kanal menjadi sangat penting dalam analisis karena akan menentukan variasi warna baik pada citra asli maupun warna pada hasil klasifikasi citra. Tampilan warna hasil klasifikasi akan memberikan kemudahan dalam menentukan batas-batas ekstrim antara setiap objek atau fenomena yang berbeda dalam sebuah lembar citra. Klasifikasi dilakukan dengan metode terbimbing, hasil klasifikasi akan menggambarkan kondisi penutupan/ penggunaan lahan aktual wilayah pesisir Kabupaten Pinrang dan sekitarnya pada setiap periode perekaman citra. Hasil sementara klasifikasi citra berupa Peta Hasil Klasifikasi Citra.

Peta dasar hasil digitasi dan peta digital hasil klasifikasi diintegrasikan untuk menghasilkan peta awal (Danoedero, 1996). Peta awal tersebut dikoreksi keakuratannya melalui survai. Survai lapang dilakukan untuk mengadopsi berbagai data dan referensi yang ada kaitannya dengan perubahan fungsi dan tata guna lahan yang berimplikasi langsung terhadap penambahan luas tambak dan arah distribusinya dalam setiap kurun waktu. Data spasial berupa batas wilayah antara tambak dengan sawah menjadi prioritas utama untuk dijadikan bahan kajian perubahan penggunaan lahan.

Data dan referensi yang diperoleh dari survai lapang digunakan untuk melakukan reinterpretasi citra dan peta awal. Reinterpretasi terutama dilakukan untuk mengoreksi bias-bias poligon tambak pada citra hasil klasifikasi dan peta awal sehingga diperoleh hasil luas tambak aktual yang akurat. Proses reinterprestasi menghasilkan luasan tambak terkoreksi, selanjutnya dibuat peta akhir yang menggambarkan secara spasial sebaran tambak di Kabupaten Pinrang.

\section{HASIL DAN BAHASAN}

Penyajian data luas tambak di Kabupaten Pinrang menunjukkan adanya perbedaan antara sumber data yang satu dengan lainnya (Tabel 1). Pada tahun 2000, luas tambak di Kabupaten Pinrang mencapai 15.375 ha (Anonim, 2003a), angka yang sama juga dilaporkan untuk tahun 2001, 2002, dan 2003 (Anonim, 2003b). Pada tahun 1990 luas tambak di Kabupaten Pinrang mencapai 12.032 ha (Anonim, 1991) dan meningkat menjadi 12.774 ha pada tahun 1999 (Anonim, 2000) atau terjadi peningkatan luas tambak sebesar 742 ha selama 1 dekade. Di pihak lain, dalam kurun waktu yang sama (1990-1999) konversi sawah tadah hujan menjadi tambak mencapai 6.287 ha di Kabupaten Pinrang (Anonim, 1999 dalam Sanusi, 2001). Tabel 1 menunjukkan luas tambak yang berbeda dari sumber yang berbeda pada tahun yang sama yaitu tahun 1998 dan 1999. Berdasarkan informasi tersebut maka data yang tersedia tidak cukup memberikan keterangan yang pasti tentang 


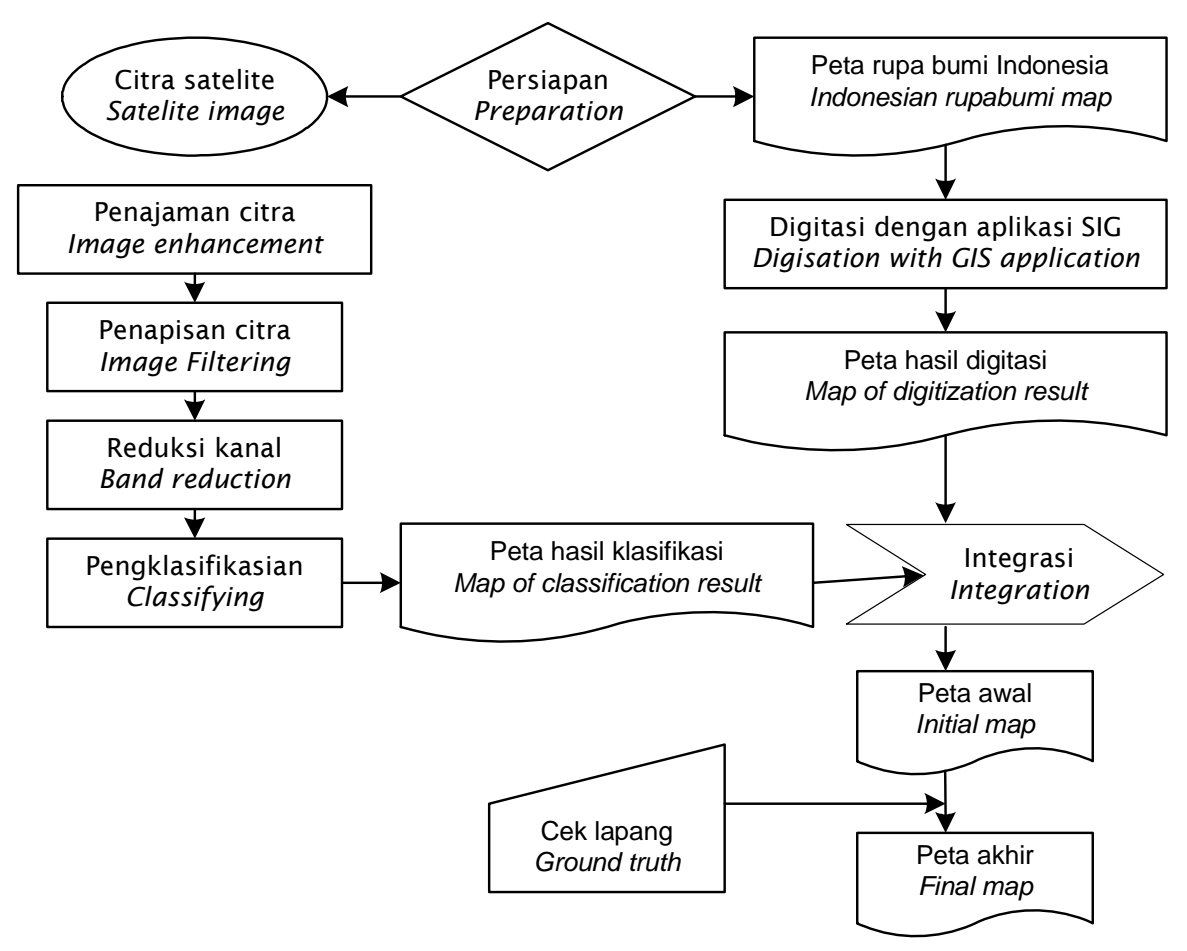

Gambar 1. Diagram alir analisis spasial dalam penentuan potensi lahan budi daya tambak (Mustafa et al., 2006)

Figure 1. Cycle diagram of spacial analysis in determinating the potency brackish water cultured pond area

Tabel 1. Luas tambak Kabupaten Pinrang periode tahun 1994-2003 dari sumber yang berbeda

Table 1. Brackishwater pond area in Pinrang Regency 1994-2003 from some different source

\begin{tabular}{cc}
\hline $\begin{array}{c}\text { Tahun } \\
\text { Year }\end{array}$ & $\begin{array}{c}\text { Luas tambak } \\
\text { Pond area } \\
\text { (ha) }\end{array}$ \\
\hline 1994 & $9,235.28$ \\
1995 & $10,209.80$ \\
1996 & $10,989.60$ \\
1997 & $11,613.21$ \\
1998 & $\mathbf{1 1 , 8 1 3 . 2 1}$ \\
1999 & $\mathbf{1 2 , 0 4 3 . 0 0}$ \\
\hline
\end{tabular}

Sumber:BPS Kabupaten Pinrang tahun 1999 (Anonim, 1999)

Source:Central Burean of Statistic Pinrang Regency in 1999 (Anonim, 1999)

\begin{tabular}{cc}
\hline $\begin{array}{c}\text { Tahun } \\
\text { Year }\end{array}$ & $\begin{array}{c}\text { Luas tambak } \\
\text { Pond area } \\
\text { (ha) }\end{array}$ \\
\hline 1998 & $\mathbf{1 1 , 6 3 1 . 2 1}$ \\
1999 & $\mathbf{1 1 , 6 3 1 . 2 1}$ \\
2000 & $15,375.00$ \\
2001 & $15,375.00$ \\
2002 & $15,375.00$ \\
2003 & $15,735.00$ \\
\hline
\end{tabular}

Sumber:Kabupaten Pinrang Dalam Angka Tahun 2003 (Anonim, 2003b)

Source:Pinrang Regency in Quantitative Data in 2003 (Anonim, 2003b) 
luas tambak sesungguhnya di Kabupaten Pinrang. Informasi tentang keakuratan data luas tambak sangat dibutuhkan oleh semua pihak terutama yang bersentuhan langsung dengan kegiatan perikanan budi daya, data tersebut akan dimanfaatkan sebagai dasar penentuan arah dan strategi pemanfaatan dan pengelolaan tambak eksisiting dan potensial.

Validasi luas tambak melalui pendekatan pamanfaatan teknik penginderaan jauh dan SIG sangat penting dilakukan untuk merevisi data luas tambak yang ada selama ini di Kabupaten Pinrang. Hasil analisis data penginderaan jauh dan SIG menunjukkan data luas tambak dan sawah (Tabel 2) beserta sebaran spasialnya (Gambar 2, 3, 4, dan 5) di wilayah pesisir Kabupaten Pinrang tahun 1991, 2002 dan 2005. Tahun 1991-2002 terjadi perluasan tambak sebesar 5.875 .281 ha $(78,43 \%)$, terjadi penambahan luas 534,116 ha $(7,13 \%)$ pertahun. Kurun waktu 2002-2005 terdapat penambahan luas tambak $1.203 .094 \mathrm{ha}(9,00 \%)$ dengan pertambahan 401.03 ha $(3,00 \%)$ pertahun. Di lain pihak pada tahun 1991-2002 terjadi penurunan luas sawah 5.720 .804 ha (28,43\%), atau 2,58\% (520.07 ha) pertahun. Sedangkan antara tahun 2002-2005 penurunan luas sawah sebesar 796.041 ha $(5,53 \%)$ atau 265.347 ha $(1,84 \%)$ per tahun.

Hasil analisis (Tabel 3) menggambarkan bahwa antara tahun 1991-2002 konversi lahan menjadi tambak hampir seluruhnya berasal dari lahan sawah $(97,37 \%)$ dan hanya 2,63\% berasal dari konversi lahan lain. Antara tahun 2002-2005 konversi lahan menjadi tambak sebagian berasal dari lahan sawah $(66,16 \%)$ dan sebesar $33,84 \%$ berasal dari konversi lahan lain. Hal yang sama juga terjadi pada kurun waktu antara tahun 1991-2005 di mana penambahan luas tambak sebagian besar berasal dari konversi sawah $(92,07 \%)$ dan hanya $7,93 \%$ perluasan tambak berasal dari konversi lahan lain. Data luas tambak dan sawah serta perubahannya per kecamatan di wilayah pesisir Kabupaten Pinrang tahun 1991, 2002, dan 2005 disajikan pada Tabel 4.

Hasil analisis nilai konversi lahan untuk setiap kecamatan antara tahun 1991-2002 dan antara tahun 2002-2005 (Tabel 5 dan 6) menunjukkan telah terjadi konversi lahan sawah menjadi tambak. Penambahan luas tambak pada tahun 1991-2002 sebesar $16,67 \%-100 \%$ berasal dari konversi sawah, konversi terbesar terjadi di Kecamatan Mattirosompe. Pada tahun 2002-2005 penambahan luas tambak $26,26 \%-100 \%$ berasal dari konversi sawah, konversi terbesar terdapat di Kecamatan Cempa.

Laju penambahan luas tambak dari hasil konversi sawah merupakan data yang sangat menarik untuk dikaji, mengingat di Provinsi Sulawesi Selatan telah dicanangkan program perwilayahan komoditas, di mana Kabupaten Pinrang sebagai salah satu sentra produksi beras dalam program tersebut. Perubahan lahan sawah menjadi tambak merupakan keinginan masyarakat secara sadar yang dimotivasi oleh tingginya nilai produksi tambak bila dibandingkan dengan produksi sawah. Berdasarkan hasil wawancara dengan masyarakat diperoleh informasi bahwa konversi lahan dari sawah menjadi tambak biasanya dilakukan pada malam hari untuk menghindari pengamatan dari pemerintah setempat. Konversi dilakukan tanpa mempertimbangkan faktor kesesuaian lahan dan kemungkinan terjadinya risiko.

Pada perkembangannya sampai tahun 2006 , terus terjadi penurunan produksi tambak di Kabupaten Pinrang. Penurunan produksi tersebut diakibatkan oleh faktor pengelolaan tambak yang tidak tepat sehingga berakibat

Tabel 2. Luas tambak dan sawah di wilayah pesisir Kabupaten Pinrang pada periode tahun yang berbeda.

Table 2. Brackishwater pond area and rice field area in coastal area of Pinrang Regency in the period of different year.

\begin{tabular}{ccc}
\hline $\begin{array}{c}\text { Tahun } \\
\text { Year }\end{array}$ & $\begin{array}{c}\text { Luas tambak } \\
\text { Pond area } \\
\text { (ha) }\end{array}$ & $\begin{array}{c}\text { Luas sawah } \\
\text { Rice field area } \\
\text { (ha) }\end{array}$ \\
\hline 1991 & $7,490.805$ & $20,116.986$ \\
2002 & $13,366.086$ & $14,396.182$ \\
2005 & $14,569.180$ & $13,600.141$ \\
\hline
\end{tabular}




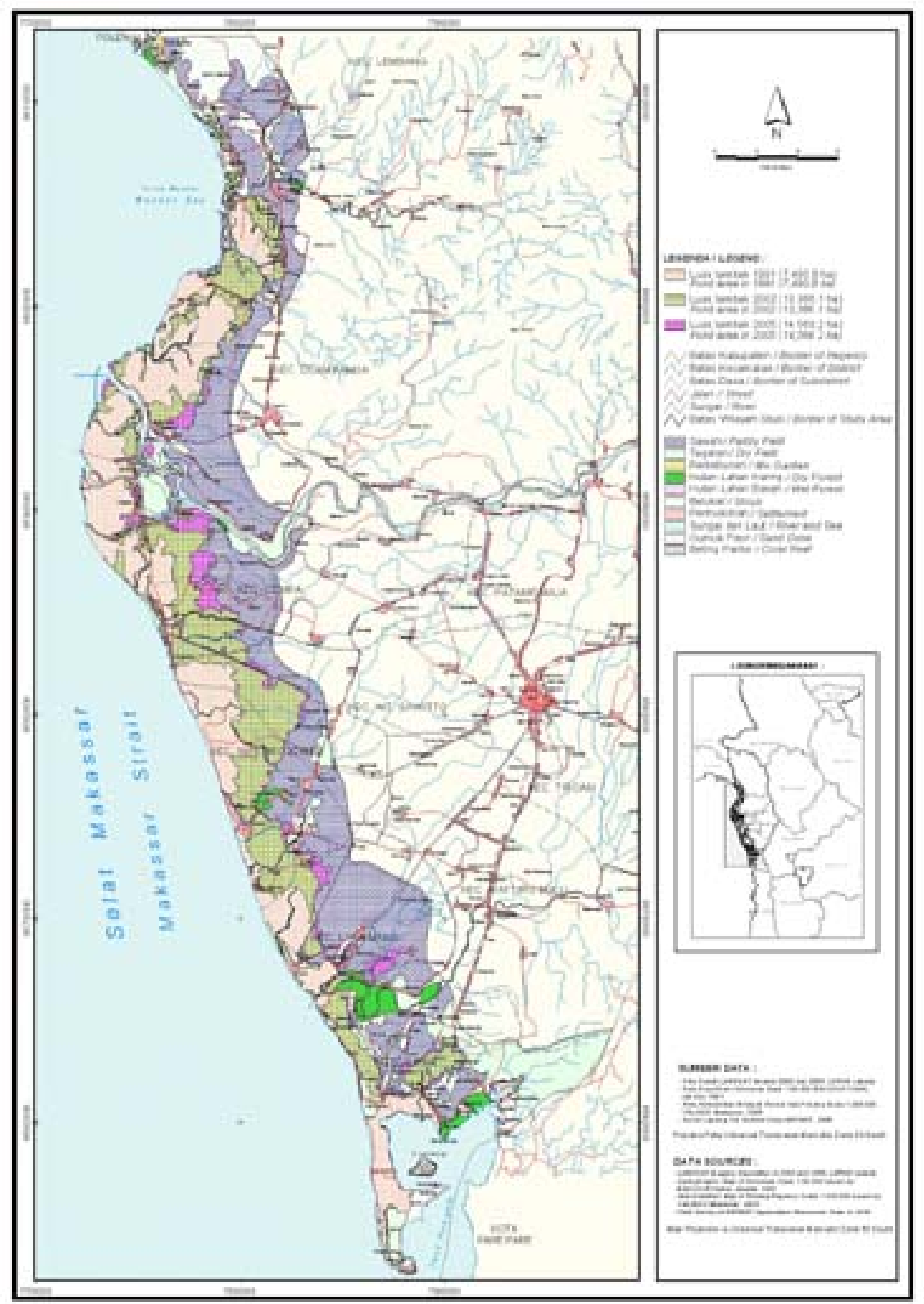

Gambar 2. Peta luasan tambak wilayah pesisir Kabupetan Pinrang Sulawesi Selatan tahun 1991, 2002, dan 2005

Figure 2. Map of brackishwater pond area in the coastal of Pinrang Regency, South Sulawesi in 1991, 2002, and 2005 


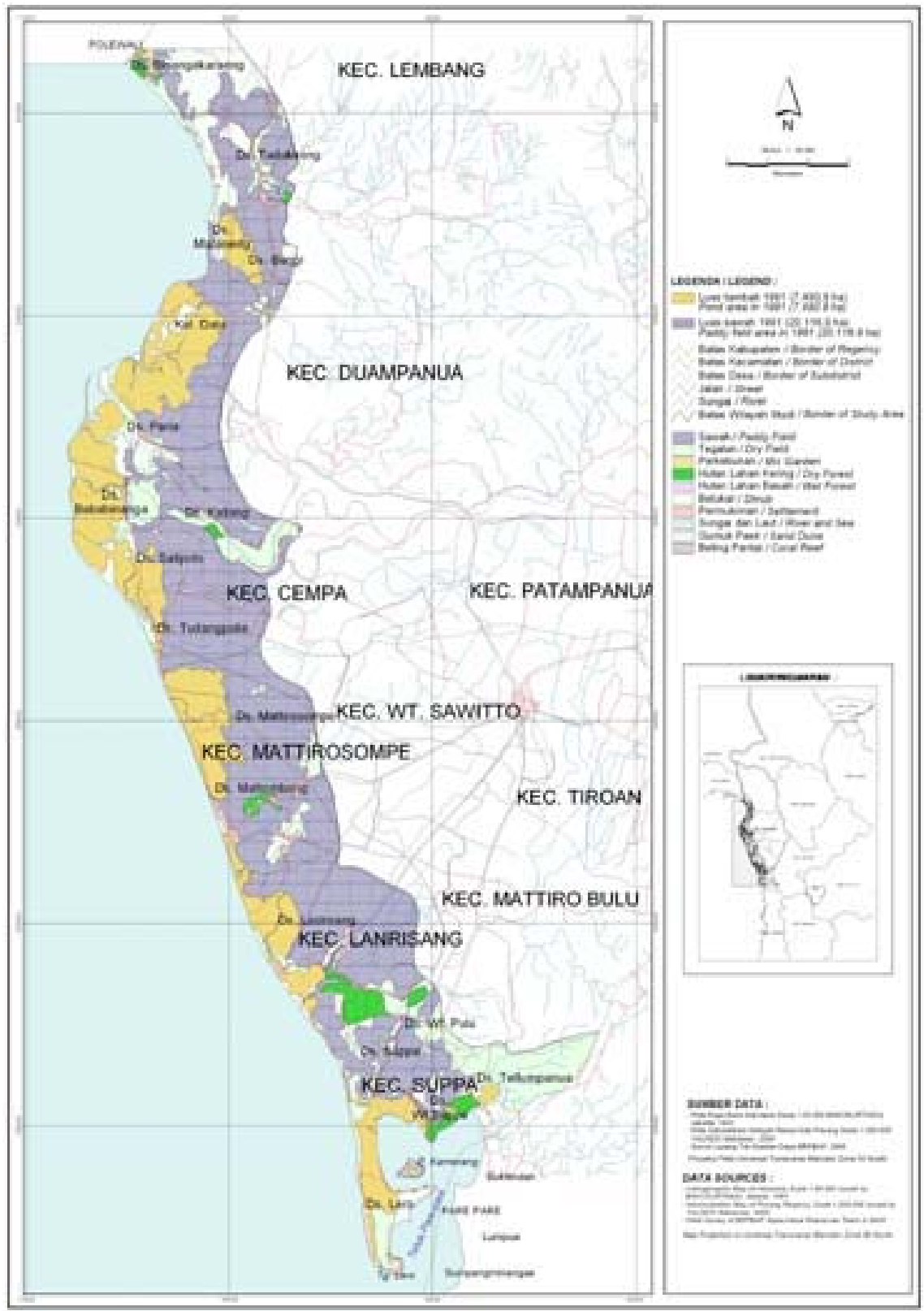

Gambar 3. Peta luasan tambak dan sawah wilayah pesisir Kabupaten Pinrang, Sulawesi Selatan tahun 1991

Figure 3. Map of brackishwater pond area and rice field area in the coastal area of Pinrang Regency, South Sulawesi in 1991 


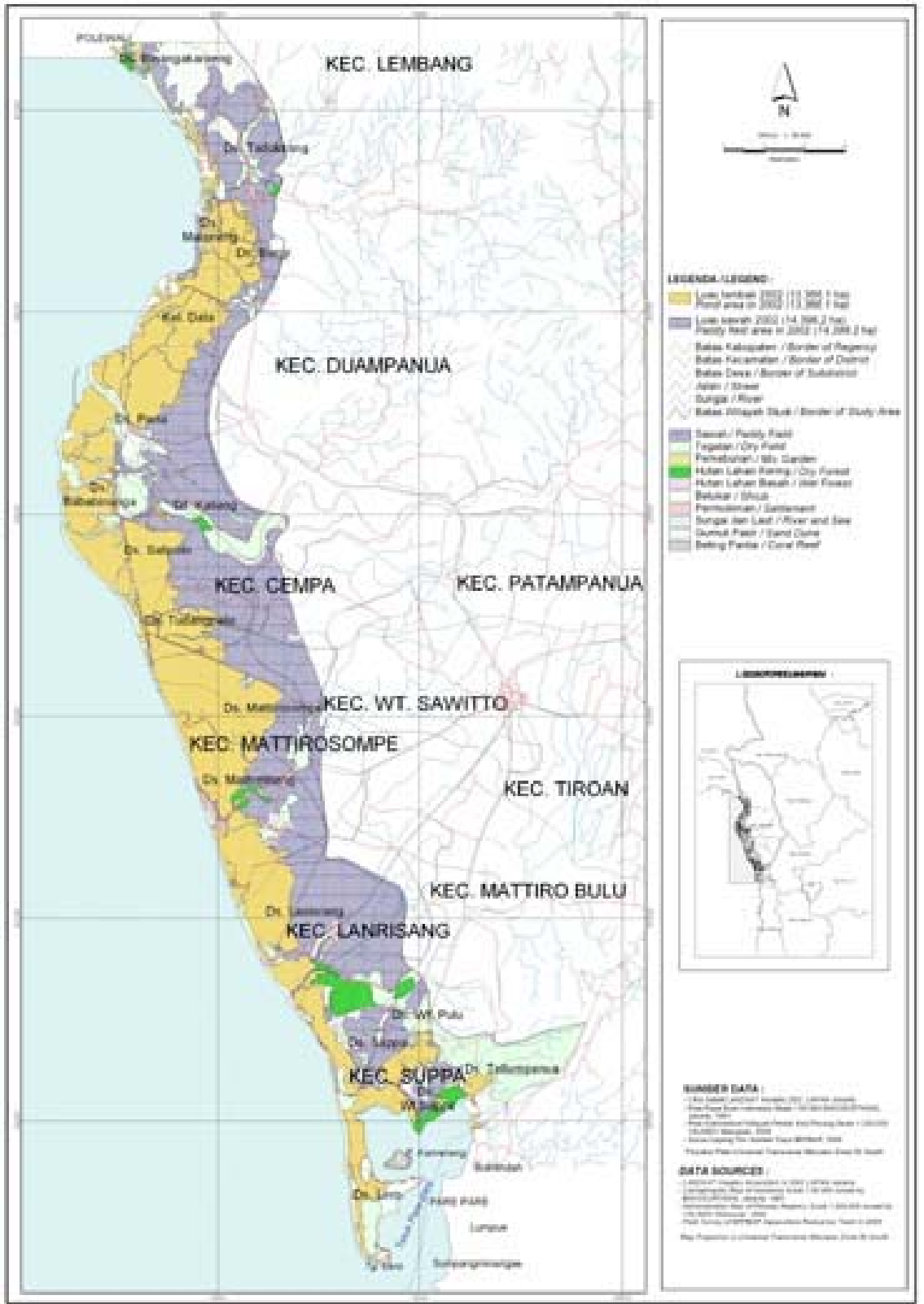

Gambar 4. Peta luasan tambak dan sawah wilayah pesisir Kabupaten Pinrang, Sulawesi Selatan tahun 2002

Figure 4. Map of brackishwater pond area and rice field area in the coastal area of Pinrang Regency, South Sulawesi in 2002 


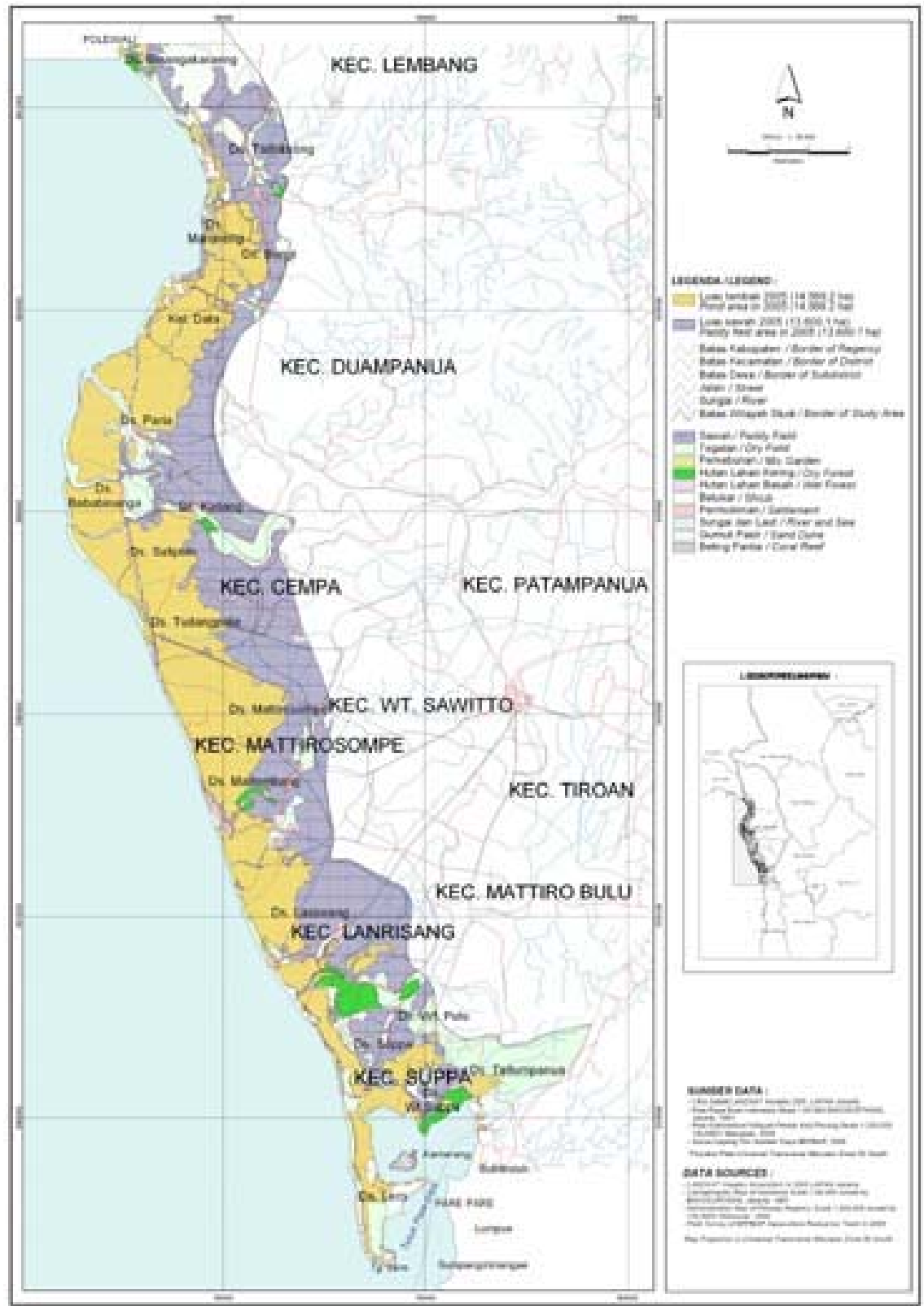

Gambar 5. Peta luasan tambak dan sawah wilayah pesisir Kabupaten Pinrang, Sulawesi Selatan tahun 2005

Figure 5. Map of brackishwater pond area and rice field area in the coastal area of Pinrang Regency, South Sulawesi in 2005 
Tabel 3. Persentasi konversi sawah menjadi tambak di wilayah pesisir Kabupaten Pinrang pada periode waktu yang berbeda

Table 3. Percentage of rice field to brackishwater pond conversion in coastal area of Pinrang Regency in the period of different year

\begin{tabular}{|c|c|c|c|c|}
\hline $\begin{array}{l}\text { Tahun } \\
\text { Year }\end{array}$ & $\begin{array}{c}\text { Pertambahan luas } \\
\text { tambak } \\
\text { Increasing of } \\
\text { brockishwater } \\
\text { pond area } \\
\text { (ha) }\end{array}$ & $\begin{array}{c}\text { Penurunan } \\
\text { luas sawah } \\
\text { Decreasing } \\
\text { of rice field area } \\
\text { (ha) }\end{array}$ & $\begin{array}{c}\text { Konversi dari sawah } \\
\text { ke tambak } \\
\text { From rice field to } \\
\text { pond conversion } \\
(\%)\end{array}$ & $\begin{array}{l}\text { Konversi dari } \\
\text { lahan lain } \\
\text { Other } \\
\text { conversion } \\
\text { (\%) }\end{array}$ \\
\hline 1991--2002 & $5,875.281$ & $5,720.804$ & 97.37 & 2.63 \\
\hline 2002--2005 & $1,203.094$ & 796,041 & 66.16 & 33.84 \\
\hline 1991--2005 & $7,078.375$ & $6,516.845$ & 92.07 & 7.93 \\
\hline
\end{tabular}

Tabel 4. Luas tambak dan sawah di wilayah pesisir Kabupaten Pinrang

Table 4. Brackishwater pond area and rice field area in coastal area of Pinrang Regency

\begin{tabular}{|c|c|c|c|c|c|c|}
\hline \multirow{3}{*}{$\begin{array}{l}\text { Kecamatan } \\
\text { District }\end{array}$} & \multicolumn{3}{|c|}{$\begin{array}{l}\text { Luas tambak } \\
\text { Pond area (ha) }\end{array}$} & \multicolumn{3}{|c|}{$\begin{array}{l}\text { Luas sawah } \\
\text { Rice field area (ha) }\end{array}$} \\
\hline & R B I 1991 & \multirow{2}{*}{$\begin{array}{l}\text { Landsat } 2002 \\
\text { Landsat } 2002\end{array}$} & \multirow{2}{*}{$\begin{array}{l}\text { Landsat } 2005 \\
\text { Landsat } 2005\end{array}$} & \multirow{2}{*}{$\begin{array}{l}\mathrm{RBI} 1991 \\
\text { IRM } 1991\end{array}$} & \multirow{2}{*}{$\begin{array}{l}\text { Landsat } 2002 \\
\text { Landsat } 2002\end{array}$} & \multirow{2}{*}{$\begin{array}{l}\text { Landsat } 2005 \\
\text { Landsat } 2005\end{array}$} \\
\hline & IRM 1991 & & & & & \\
\hline Cempa & 875.755 & $2,228.853$ & $2,680.011$ & $3,694.507$ & $2,443.084$ & $2,086.868$ \\
\hline Duam panua & $3,417.010$ & $4,660.200$ & $5,078.169$ & $4,475.389$ & $3,314.612$ & $3,204.834$ \\
\hline Lanrisang & 722.223 & 997.281 & $1,257.807$ & $3,158.646$ & $2,882.277$ & $2,612.003$ \\
\hline Lembang & - & 142.933 & 169.764 & $1,663.619$ & $1,639.793$ & $1,629.366$ \\
\hline $\mathrm{M}$ attirosompe & $1,465.854$ & $3,647.830$ & $3,702.714$ & 5,161178 & $2,934.444$ & $2,870.445$ \\
\hline Suppa & $1,009.963$ & $1,688.989$ & $1,680.715$ & $1,963.647$ & 1,181972 & $1,196.625$ \\
\hline Total & $7,490.805$ & $13,366.086$ & $14,569.180$ & $20,116.986$ & $14,396.182$ & $13,600.141$ \\
\hline
\end{tabular}

Tabel 5. Luas tambak dan konversi sawah per kecamatan di Kabupaten Pinrang pada periode tahun 1991-2002

Table 5. Brackishwater pond area and rice field conversion each district in Pinrang Regency in the period of year 1991-2002

\begin{tabular}{|c|c|c|c|c|}
\hline \multirow[b]{2}{*}{$\begin{array}{c}\text { Kecamatan } \\
\text { District }\end{array}$} & \multicolumn{4}{|c|}{ Tahun (Year ) 1991-2002 } \\
\hline & $\begin{array}{l}\text { Pertambahan } \\
\text { luas tambak } \\
\text { Increasing of } \\
\text { brockishwater } \\
\text { pond area (ha) }\end{array}$ & $\begin{array}{c}\text { Penurunan } \\
\text { luas sawah } \\
\text { Decreasing of rice } \\
\text { field area (ha) }\end{array}$ & $\begin{array}{l}\text { Konversi dari } \\
\text { sawah ke tambak } \\
\text { From rice field } \\
\text { to pond } \\
\text { conversion (\%) }\end{array}$ & $\begin{array}{c}\text { Konversi dari } \\
\text { lahan lain } \\
\text { Other } \\
\text { conversion } \\
(\%)\end{array}$ \\
\hline Cempa & $1,353.098$ & 1,251423 & 92.48 & 7.52 \\
\hline Duampanua & $1,243.190$ & $1,160.777$ & 93.37 & 6.63 \\
\hline Lanrisang & 275.058 & 276.369 & 100.00 & - \\
\hline Lembang & 142.933 & 23.826 & 16.67 & 83.33 \\
\hline M attirosompe & 2,181976 & $2,226.733$ & 100.00 & - \\
\hline Suppa & 679,026 & 781675 & 100.00 & - \\
\hline
\end{tabular}


Tabel 6. Luas tambak dan konversi sawah per kecamatan di Kabupaten Pinrang pada periode tahun 2002-2005

Table 6. Brackishwater pond area and rice field conversion each district in Pinrang regency in the period of year 2002-2005

\begin{tabular}{lcccc}
\hline \multirow{2}{*}{$\begin{array}{c}\text { Kecamatan } \\
\text { District }\end{array}$} & $\begin{array}{c}\text { Pertambahan } \\
\text { luas tambak } \\
\text { Increasing of } \\
\text { brockishwater } \\
\text { pond area } \\
\text { (ha) }\end{array}$ & $\begin{array}{c}\text { Tenurunan } \\
\text { luas sawah } \\
\text { Decreasing of rice } \\
\text { field area }\end{array}$ & $\begin{array}{c}\text { Konversi dari } \\
\text { sawah ke tambak } \\
\text { From rice field } \\
\text { to pond conversion }\end{array}$ & $\begin{array}{c}\text { Konversi dari } \\
\text { Other conversion } \\
\text { lahan lain }\end{array}$ \\
\hline Cempa & 451,158 & (ha) & (\%) & (\%) \\
Duampanua & 417,969 & 356,216 & 78,95 & 21,05 \\
Lanrisang & 260,526 & 109,778 & 26,26 & 73,74 \\
Lembang & 26,831 & 270,274 & 100 & - \\
Mattirosompe & 54,884 & 10,427 & 38,86 & 61,14 \\
Suppa & $-8,274$ & 63,999 & 100 & - \\
\hline
\end{tabular}

munculnya serangan penyakit yang melanda semua hamparan tambak yang ada di Kabupaten Pinrang. Fakta ini menjadi pemicu keinginan masyarakat untuk mengembalikan lahan sawah yang telah dikonversi menjadi tambak. Namun demikian usaha masyarakat tersebut tidak berjalan sesuai dengan rencana, mengingat karakteristik lahan fisik dan biokimia tambak sangat berbeda dengan lahan sawah, butuh waktu yang lama untuk mengembalikan keadaan normal lahan sawah.

\section{KESIMPULAN}

Dari kajian yang telah dilakukan maka dapat disimpulkan:

1. Luas tambak di Kabupaten Pinrang pada tahun 1991, 2002, dan 2005 masing-masing adalah $7.490,805$ ha; $13.366,086$ ha; dan $14.569,180$ ha.

2. Pada tahun 1991-2005 penambahan luas tambak sebesar $92,07 \%$ berasal dari konversi sawah dan hanya $7,93 \%$ berasal dari lahan lain.

3. Konversi sawah terbesar yang dijadikan sebagai tambak pada tahun 1991-2002 terdapat di Kecamatan Mattirosompe, sedangkan pada tahun 2002-2005 terdapat di Kecamatan Cempa.

\section{UCAPAN TERIMA KASIH}

Ucapan terima kasih disampaikan kepada Darsono, Muh. Arnol, dan Hasyim Saud atas konstribusinya selama survai lapangan.
Penelitian ini dibiayai oleh APBN Tahun Anggaran 2006.

\section{DAFTAR PUSTAKA}

Ahmad, T., A. Mustafa, dan A. Hanafi. 1996. Konsep Pengembangan Desa Pantai Mendukung Keberlanjutan Produksi Perikanan Pesisir. Dalam A. Poernomo, H. E. Irianto, S. Nurhakim, Murniyati dan E. Pratiwi (Eds.), Prosiding Rapat Kerja Teknis Peningkatan Visi Sumberdaya Manusia Peneliti Perikanan Menyongsong Globalisasi IPTEK, Serpong, 19-20 November 1996. Pusat Penelitian dan Pengembangan Perikanan, Jakarta. 91-106 pp.

Anonim. 1991. Laporan Statistik Perikanan Sulawesi Selatan 1991. Dinas Perikanan Propinsi Daerah Tingkat I Sulawesi Selatan, Ujung Pandang. 119 pp.

Anonim. 1999. Laporan Statistik Perikanan Kabupaten Pinrang 1999. Dinas Perikanan Kabupaten Pinrang. 17 pp.

Anonim. 2000. Laporan Statistik Perikanan Sulawesi Selatan 1999. Dinas Perikanan Propinsi Sulawesi Selatan, Makassar. 119 pp.

Anonim. 2003a. Laporan Statistik Perikanan Sulawesi Selatan 2002. Dinas Perikanan dan Kelautan Propinsi Sulawesi Selatan, Makassar. $119 \mathrm{pp}$.

Anonim. 2003b. Kabupaten Pinrang Dalam Angka (Pinrang Regency In Figures). Kerja 
sama Badan Pusat Statistk Kabupaten Pinrang dengan Bappeda Kabupaten Pinrang. BPS Kabupaten Pinrang. 217 pp.

Danoedero, P. 1996. Pengolahan Citra Digital: Teori dan Aplikasinya dalam Bidang Penginderaan Jauh. Fakultas Geografi, Universitas Gadjah Mada, Yokyakarta. P. 1819.

Dennis, M., T. Tammy, K. Baldwin, and F. Kevin. 2004. Aquaculture Development Potential in Arizona: a GIS-Based Approach. World Aquaculture 34 (4): 32-35.

Kushardono, D. 1999. Klasifikasi Penutup/ Penggunaan Lahan Dari Data Inderaja. Dalam: Suharmanto, F. Tjinda, S. Yulmontoro, I L. Arisdyo, R. Ginting dan A. Effendi (Eds.). Pengantar Teknologi, Aplikasi Penginderaan Jauh Satelit dan Sistem Informasi Geografi. Lembaga Penerbangan dan Antariksa Nasional dan Badan Pengkajian dan Penerapan Teknologi, Jakarta. p. 167-184.

Lo, C. P. 1996. Pengindraan Jauh Terapan. Diterjemahkan oleh: B. Purbowaseno. Universitas Indonesia Press, Jakarta. 275 pp.

Mustafa et al, 2006. Validasi luas Iahan budidaya tambak di Kabupaten Maros dan Pangkep Provinsi Sulawesi Selatan dengan menggunakan teknologi penginderaan jauh dan sistem informasi geografis. Laporan Penelitian. Balai Riset Perikanan Budidaya Air Payau, Maros. 20 pp.

Mustafa et al. 2004. Karakteristik dan Kelayakan Lahan Budidaya Tambak di Kecamatan
Sampara Kabupaten Kendari Provinsi Sulawesi Tenggara. J. Pen. Per. Indonesia, Edisi Akuakultur, Vol. 10 No.2. Jakarta. 113 pp.

Mustafa, A. dan A. Hanafi. 1996. Pola Penataan Kawasan Tambak Berwawasan Lingkungan. Makalah disajikan pada "Rapat Kerja Teknis Balai Penelitian Perikanan Pantai", Makassar 17-18 April 1996. Balai Penelitian Perikanan Pantai, Maros. 18 pp.

Pérez, O. M., L. G. Ross, T. C. Telfer, and L. M. Del Campo Barquin. 2003. Water Quality Requirements For Marine Fish Cage Site Selection in Tenerife (Canary Islands): predictive modelling and analysis using GIS. Aquaculture 224: 51-68.

Salam, M. A., N. A. Khatun and M. M. Ali. 2005. Carp Farming Potential in Barhatta Upazilla, Bangladesh: a GIS methodological perspective. Aquaculture 245: 75-87.

Sanusi, A. 2001. Konversi Lahan Sawah Menjadi Tambak Ditinjau dari Pendapatan Petani. Tesis. Program Pascasarjana Universitas Hasanuddin, Makassar.

Sitanggang, G.M. 1999. Pemanfaatan Data Penginderaan Jauh Untuk Aplikasi Darat. Dalam: Suharmanto, F. Tjinda, S. Yulmontoro, I L. Arisdyo, R. Ginting dan A. Effendi (Eds.), Pengantar Teknologi, Aplikasi Penginderaan Jauh Satelit dan Sistem Informasi Geografi. Lembaga Penerbangan dan Antariksa Nasional dan Badan Pengkajian dan Penerapan Teknologi, Jakarta. p. 225-240. 